\title{
ETHICS WITH AN ATTITUDE: COMMENTS ON NEW DIRECTIONS FOR KECK PHILANTHROPY
}

\author{
TIMOTHY P. TERRELL*
}

I

OF METHODS AND GOALS

The opening panel presentation at the conference that spawned this issue of Law and Contemporary Problems described innovations at several law schools in the traditional survey course in legal ethics. As moderator of that presentation, I suggested the following diagram as a summary of the issues that ought to be addressed in redesigning that course:

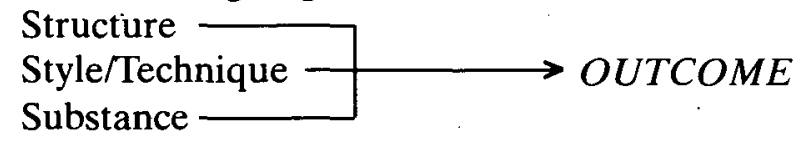

I also observed, however, that although the panelists' papers had much to say about the topics on the left of the diagram-for example, whether the course should be two or three credit hours, be compressed within a short time or spread over a semester, be offered in the first year of law school or required in later years, use traditional case analysis or rely on new forms of instruction, urge a particular moral perspective or be more agnostic, and so on-they had rather little to say about the important matter to the right.

Remaining largely implicit for much of the conference was a fundamental issue: What are we trying to produce with this strong emphasis on inculcating ethical values (or at least an appreciation of ethical values) into law students? Better lawyers? How so? Nicer Lawyers? How so and why? Happier Lawyers? Happier Clients? Or is the point a better, nicer legal system? Or a better, nicer, happier society? I returned to this issue at the end of the conference by noting that even after two days of very impressive conversation, it was still unclear to me how the conference attendees would answer the "outcome" question.

This relative inattention is significant (although not disastrous) because one's goal can often determine one's methods. And the more distinct the goals at stake, the more difficult it will be for educators to generate any consensus on a course's structure, style, and substance. The conference, it seems to me, demonstrated this phenomenon, even among scholars who were all committed to "improving" legal ethics training. 
II

\section{Competing "Old" and "New" Moral Perspectives}

The W.M. Keck Foundation has funded a wide range of different kinds of instructional efforts that reflect-but also disguise-a subtle underlying competition between two alternative visions of what this enhanced teaching is supposed to achieve. One has its roots in the past, the basic message of which is that the legal profession once had a sense of ethics to which current practitioners and students should return and perhaps improve. The other has its foundation in the present, and its basic message is that ethics training is part of a modern effort to create something new within the practice of law that will help revitalize and justify it. These differing perspectives in turn produce two very different teaching approaches. The first, in an effort to understand legal ethics, elevates the importance of the history and current context of law practice; the latter demotes these elements and instead emphasizes contemporary moral and political philosophy. Most conference participants seemed to be committed to the latter vision and teaching approach, but without much thought concerning implications for the relationship between law schools and law practice.

Despite this important underlying difference between types of ethics courses, all the programs described at the conference nevertheless share an equally important characteristic: They are motivated by an intuition that typical law school ethics training, which is usually mired myopically in rules of acceptable behavior, is insufficient to produce either the improved old thing or the refreshing new thing. Everyone seems to concede that the rules of legal ethics are necessarily incomplete in their guidance and inspiration. What everyone is seeking to produce, then, is a vague condition of mind within which these ethics rules should be learned, interpreted, and applied. I call this particular propensity "ethics with an attitude"; practicing lawyers generally refer to something like it as "professionalism." " Yet, whatever it might be labeled, it is considered the factor capable of resuscitating the morality of lawyering.

If this is true, then the directions of Keck Foundation philanthropy regarding legal ethics should change. But not because the Foundation's previous efforts have been misguided. The problem the Foundation now confronts is a function of its success: There seems little more it can do in the law school arena that would not simply repeat or overlap unnecessarily with efforts it has already launched. For example, the Foundation has already helped law schools create ample videotape-based training programs and other innovative teaching materials to enrich ethics courses generally. These materials now need to be

1. Professionalism is not synonymous with this attitude, however, because "professionalism" is usually understood by lawyers either very superficially or more narrowly than the outcome the conference participants have in mind. A host of recent articles demonstrate this point in various ways, and many have been assembled into a book by the organizer of this conference, Professor Thomas Metzloff of Duke University School of Law. See ThOMAS B. METZLOFF, PROFESSIONAL RESPONSIBILITY ANTHOLOGY (1994). 
distributed more widely rather than increased in amount or sophistication, a task that can and should be handled by others. The Foundation should instead turn its attention to a different set of challenges and opportunities involving legal ethics and the future of the legal profession.

\section{III}

\section{LAW Practice VERSUS LAW SCHOOLS}

The educational emphasis for the Keck Foundation should shift to the busy practitioner. In these circumstances, the topic of professional responsibility is no longer theoretical and about other people; it is tangible, immediate, and personal. Here, attitude - at least as much as rules-determines the real nature of legal ethics. Here, then, the legal profession will ultimately succeed or fail in regaining and maintaining some semblance of social respectability.

Yet here, unfortunately, is also where law schools have their least interest. For reasons too numerous and complex to sort out in this brief comment, a significant and troubling division has developed between law schools and law practice, fueled by mutual attitudes of disdain, with each side attending to separate agendas that few have any interest in integrating. This division needs to be reduced in general, but particularly regarding the basic moral expectations of and within the profession. On this point, the Keck Foundation has already been helpful. For example, it financially assisted law schools in developing the videotape training materials mentioned above, which have become as popular with practicing lawyers at continuing legal education ("CLE") programs as with law students in their ethics courses. But many more steps of this kind are needed, with a specific eye to developing programs aimed principally at practitioners, and secondarily at students. Some efforts of this sort have already begun to emerge within various bar organizations.

Yet this modest, fledgling development among practicing lawyers itself raises some interesting questions for the Keck Foundation and other eleemosynary institutions. Even if everyone agreed that a fruitful place for ethics instruction would be CLE programs, a separate issue is whether philanthropic organizations ought to be involved in the Bar's effort to resurrect its reputation. One could reasonably argue, after all, that if ethics training is important to practicing lawyers, then they will, or ought to, use their own considerable resources to create it. Although to some extent they have, the real problem here is the same one that causes charitable foundations to become heavily involved in funding basic scientific research and educational institutions generally: These activities need philanthropic support because they have little immediate market appeal that would cause ordinary economic forces to fund them adequately. Foundations, then, help cure a kind of basic market failure-a strong tendency for investors to shy away from projects with very long-term, speculative pay-offs, particularly pay-offs that cannot be captured by the investors themselves. CLE training generally, and legal ethics training in particular, is in this circumstance. It needs the support of organizations with long-range, socially conscious perspectives. 
Although a change in the Keck Foundation's focus from law students to law practitioners would be both uniquely useful to the profession and fully justified, accomplishing this move raises another set of problems more practical than orientational. The Foundation could, for example, simply solicit program proposals from various bar associations or other lawyer organizations with special interests in ethics. ${ }^{2}$ But this would force the Foundation, rather uncomfortably, I think, to consider a host of proposals from non-traditional and less easily monitored sources. Instead, another route would be more manageable for the Foundation and more beneficial for the legal profession.

\section{IV \\ TOWARD JOINT PROJECTS}

The administrative challenge to the Foundation is to address two problems simultaneously, and to do so without significantly changing the way it currently conducts its philanthropic business through grants to traditional educational institutions. The two problems are those on which I have focused here. The first is one that the Foundation already appreciates and, not surprisingly, captured most of the attention at the conference: the perception that the practice of law is losing its moral integrity and social stature. The second, less obvious problem is the one I believe diminishes the practical impact of the Foundation's law school-based projects: the unhealthy, and sometimes antagonistic separation between law school and law practice. If practitioners continue to lack interest in academic efforts, innovative ethics instruction in law schools will not have the kind of lasting value the Foundation might expect.

A possible solution might adopt the following pattern. For the Foundation to accomplish several objectives simultaneously - to continue its appropriate emphasis on the moral foundations of law practice, to enhance the potential impact of programs it has already funded, and to continue to rely upon educational institutions as the principal source and locus of new projects-it should require the next generation of law-related grant proposals to be from law schools willing to establish a joint effort between themselves and bar organizations or some other kind of practice group. To that end, the Foundation should announce that its requirements will not be satisfied by any law school program that focuses primarily, or even initially, on law students, including programs that involve a few noted practicing lawyers and programs that the school ultimately intends to "sell" to practicing lawyers or bar groups for use in CLE contexts.

2. Georgia has produced one good example. A decade ago, the Chief Justice of the Georgia Supreme Court created "The Chief Justice's Commission on Professionalism," which is independent of the State Bar of Georgia, and charged it with the singular responsibility of fostering CLE training in professionalism (that is, some version of ethics with an attitude), including the creation of new and innovative teaching materials. The Commission is funded by special CLE fees paid by members of the State Bar for their annual professionalism training. The Commission's board of directors is composed principally of practicing lawyers and a few judges, but also includes representatives from each of Georgia's law schools. 
Instead, any proposed program, as initially conceived and structured, would have to reflect a collective and collaborative effort of legal academics and law practitioners, with one evident goal being to have the perspectives of each enhance and enrich the other.

An Emory Law School alumnus recently established just such a collaborative effort with the "Institute for General Counsel Studies," which will be housed at Emory but run by various general counsel of corporations and government agencies around the country. The purpose of the Institute will be to fund studies and conferences focused on the unique ethical demands imposed on general counsel because of the unusual hybrid position they occupy as lawyers for and part of management of the same companies. All Institute activities are expected to involve the joint efforts of general counsel, law professors, and law students, and to include corporate CEOs as well to help educate them concerning the nature of in-house lawyering. The Institute would therefore bridge the academic-practitioner divide as well as the law-business dichotomy. Its overall theme will be ethical responsibility, in both the legal and business arenas.

Because this kind of project emphasizes the subtle factors I have stressed here-attitude and circumstances-it ought to be of particular interest to foundations endeavoring to have a significant impact on the ethics of lawyering. Lawyers especially understand that rules alone mean little; only in context do they really matter. This insight has in fact been central to virtually all of the innovative law school teaching projects the Keck Foundation has already funded. It is time to transfer these lessons more directly into the profession, and to help law schools and bar associations fulfill their joint responsibility for doing so. 
